Research Paper

\title{
Clinicopathologic implications of immune classification by PD-L1 expression and CD8-positive tumor-infiltrating lymphocytes in stage II and III gastric cancer patients
}

\author{
Jiwon Koh ${ }^{1}$, Chan-Young Ock ${ }^{2}$, Jin Won Kim ${ }^{3}$, Soo Kyung Nam ${ }^{4}$, Yoonjin Kwak ${ }^{4}$, \\ Sumi Yun ${ }^{5}$, Sang-Hoon Ahn ${ }^{6}$, Do Joong Park ${ }^{6}$, Hyung-Ho Kim ${ }^{6}$, Woo Ho Kim ${ }^{1}$, Hye \\ Seung Lee Le $^{4}$ \\ ${ }^{1}$ Department of Pathology, Seoul National University College of Medicine, Jongno-gu, Seoul 03080, Republic of Korea \\ ${ }^{2}$ Department of Internal Medicine, Seoul National University Hospital, Jongno-gu, Seoul 03080, Republic of Korea \\ ${ }^{3}$ Department of Internal Medicine, Seoul National University Bundang Hospital, Bundang-gu, Seongnam-si, Gyeonggi-do \\ 13620, Republic of Korea \\ ${ }^{4}$ Department of Pathology, Seoul National University Bundang Hospital, Bundang-gu, Seongnam-si, Gyeonggi-do 13620, \\ Republic of Korea \\ ${ }^{5}$ Department of Pathology, Soonchunhyang University Seoul Hospital, Yongsan-gu, Seoul 04401, Republic of Korea \\ ${ }^{6}$ Department of Surgery, Seoul National University Bundang Hospital, Bundang-gu, Seongnam-si, Gyeonggi-do 13620, \\ Republic of Korea
}

Correspondence to: Hye Seung Lee, email: hye2@snu.ac.kr

Keywords: gastric cancer, programmed cell death 1 ligand 1, tumor-infiltrating lymphocytes, cancer microenvironment

Received: November 22, $2016 \quad$ Accepted: February 06, $2017 \quad$ Published: February 17, 2017

Copyright: Koh et al. This is an open-access article distributed under the terms of the Creative Commons Attribution License (CC-BY), which permits unrestricted use, distribution, and reproduction in any medium, provided the original author and source are credited.

\section{ABSTRACT}

We co-assessed PD-L1 expression and CD8+ tumor-infiltrating lymphocytes in gastric cancer (GC), and categorized into 4 microenvironment immune types. Immunohistochemistry (PD-L1, CD8, Foxp3, E-cadherin, and p53), PD-L1 mRNA in situ hybridization (ISH), microsatellite instability (MSI), and EBV ISH were performed in 392 stage II/III GCs treated with curative surgery and fluoropyrimidinebased adjuvant chemotherapy, and two public genome databases were analyzed for validation. PD-L1+ was found in $98 / 392$ GCs $(25.0 \%)$. The proportions of immune types are as follows: PD-L1+ $/$ CD8 ${ }^{\text {High, } 22.7 \% ; ~ P D-L 1-/ C D 8 ~}{ }^{\text {Low }}, 22.7 \%$; PD-L1 ${ }^{+} /$CD8 $^{\text {Low, }}$ 2.3\%; PD-L1-/CD8 ${ }^{\text {High }}, 52.3 \%$. PD-L1 ${ }^{+} / \mathrm{CD}^{\text {High }}$ type accounted for majority of EBV ${ }^{+}$ and MSI-high (MSI-H) GCs (92.0\% and $66.7 \%$, respectively), and genome analysis from public datasets demonstrated similar pattern. PD-L1-/CD8 ${ }^{\text {High }}$ showed the best overall survival (OS) and PD-L1 $-/ C D 8^{\text {Low }}$ the worst $(P<0.001)$. PD-L1 expression alone was not associated with OS, however, PD-L1-/CD8 ${ }^{\text {High }}$ type compared to PD-L1 ${ }^{+} / \mathrm{CD}^{\mathrm{High}}$ was independent favorable prognostic factor of OS by multivariate analysis $(P=0.042)$. Adaptation of recent molecular classification based on EBV, MSI, E-cadherin, and p53 showed no significant survival differences. These findings support the close relationship between PD-L1/CD8 status based immune types and EBV $^{+}$, MSI-H GCs, and their prognostic significance in stage II/III GCs.

\section{INTRODUCTION}

Gastric cancer (GC) is the fifth most common cancer worldwide [1], the third most common cancer in South Korea [2], and one of the leading causes of cancer-related death worldwide [3]. The close relationship between $\mathrm{GC}$ carcinogenesis and chronic inflammation caused by Helicobacter pylori and Epstein-Barr virus (EBV) infection has been investigated $[4,5]$, and this unique immune environment is expected to be an effective target of therapy [6].

Clinical trials of immune checkpoint inhibitors have shown favorable outcomes in some solid tumors, including GC [7-9]. Currently, cell surface expression of 
PD-L1, as assessed by immunohistochemistry (IHC), is a predictive factor for the response to immune checkpoint inhibitors; however, not all patients benefit from this therapy [10]. Therefore, recent studies have focused on how to predict which patients would clinically benefit from cancer immunotherapy and what lies beyond the mechanism of immune escape. A schematic of the tumor microenvironment immune type (TMIT) was developed for better understanding of immune microenvironment. The classification is based on the expression of PDL1 and tumor-infiltrating lymphocytes (TILs) and consists of four types as follows: type I (PD-L1 ${ }^{+} / \mathrm{TIL}^{\text {High }}$, adaptive immune resistance), type II (PD-L1 ${ }^{-} / \mathrm{TIL}^{\mathrm{Low}}$, immune ignorance type), type III (PD-L1 ${ }^{+} / \mathrm{TIL}^{\mathrm{Low}}$, intrinsic induction of PD-L1 in the absence of TILs), and type IV (PD-L1 ${ }^{-} / \mathrm{TIL}^{\text {High }}$, components other than PD-L1 suppressing the action of TILs) [11]. Though this stratification was criticized for being too simplistic [12], a comprehensive analysis of The Cancer Genome Atlas (TCGA) dataset for various solid tumors, which used $C D 8 A$ expression as a surrogate marker for TILs, revealed significant association between TMIT I ( $P D$ $L 1^{\text {High }} / C D 8 A^{\text {High }}$ ) and features like high mutational burden and oncogenic viral infection, suggesting the clinical relevance of this classification [13].

Recent studies suggest that the type of TILs, especially CD8-positive $\left(\mathrm{CD}^{+}\right)$cytotoxic $\mathrm{T}$ cells, is important for the action of immune checkpoint inhibitors [14]. In GC, EBV-positive $\left(\mathrm{EBV}^{+}\right) \mathrm{GCs}$ and MSI-high (MSI-H) GCs are frequently accompanied by heavy infiltration of TILs $[15,16]$, which may be associated with a favorable response to immune checkpoint blockades. However, other GCs are heterogeneous. Recent studies have proposed that additional markers, including epithelial-mesenchymal transition (EMT) features and TP53 mutations, could be used for further molecular classification [17, 18], although little is known about these categories from a tumor microenvironment-related perspective.

Considering the importance of both PD-L1 expression and $\mathrm{CD} 8^{+}$TILs in defining the tumor immune microenvironment [11-13], we co-assessed PD-L1 expression by immunohistochemistry and the density of $\mathrm{CD}^{+}$TILs in GC tissue samples and applied the scheme for TMIT classification based on PD-L1 expression/CD8 status. The purpose of this study was to (i) determine the association between TMIT and clinicopathologic features, especially prognostic significance, in stage II and III GCs, as well as the molecular subtypes of GCs, specifically EBV and MSI status, (ii) validate the findings by analysis of publicly available genomic datasets, and (iii) suggest potential biomarkers for better patient selection for immune checkpoint inhibitor therapy.

\section{RESULTS}

\section{Clinicopathologic characteristics and gene expression status}

The baseline clinicopathologic characteristics of the study population are shown in Table 1 . The median age was 59 years (range, 20-87 years). Of the 392 patients, 210 (53.6\%) were AJCC 7th TNM stage II, and 182 (46.4\%) were stage III. Fluoropyrimidine (FP)-based regimen was applied as adjuvant chemotherapy; 336 patients (85.7\%) were treated with FP only, and 56 patients $(14.3 \%)$ were treated with FP and cisplatin. The number of CD8 ${ }^{+}$TILs ranged from 6.90 cells $/ \mathrm{mm}^{2}$ to 1374.94 cells $/ \mathrm{mm}^{2}$ with the median value of 195.23 cells $/ \mathrm{mm}^{2}$. The number of Foxp3 $3^{+}$ TILs ranged from 1.22 cells $/ \mathrm{mm}^{2}$ to 785.88 cells $/ \mathrm{mm}^{2}$ with the median value of 60.12 cells $/ \mathrm{mm}^{2}$.

PD-L1 IHC was positive in 98 samples $(25.0 \%)$, and $P D-L 1$ mRNA overtranscription (a $P D-L 1$ mRNA ISH score of $4+$ ) was detected in 14 samples $(3.6 \%)$. When PD-L1 IHC and mRNA ISH were compared, all cases with mRNA ISH score of $4+$ were PD-L1 IHC positive, and the correlation coefficient between the 2 tests was 0.467 , which was statistically significant at the 0.01 level (Supplementary Table 1). Altered expression of E-cadherin was detected in 61 of 392 samples (15.6\%), and overexpression of p53 was detected in 108 of 392 samples $(27.6 \%)$.

\section{Immune and molecular classification of GCs}

We categorized the study population into TMITs I-IV based on the results of PD-L1 IHC and CD8 ${ }^{+}$ TIL density (Figure 1). The number and proportion of each type were as follows: type I (PD-L1 $\left.1^{+} / \mathrm{CD}^{\mathrm{High}}\right)$, 89 (22.7\%); type II (PD-L1 $\left.{ }^{-} / \mathrm{CD}^{\mathrm{Low}}\right), 89$ (22.7\%); type III (PD-L1 $\left.{ }^{+} / \mathrm{CD}^{\mathrm{Low}}\right), 9$ (2.3\%); and type IV (PD$\left.\mathrm{L}^{-} / \mathrm{CD} 8^{\mathrm{High}}\right), 205$ (52.3\%). Type I showed more male predominance than the other types $(P=0.021)$, and AJCC 7th pT stage was significantly associated with TMIT $(P=0.004)$. In addition, type I was associated with Foxp $3^{\text {High }}$ status, and type II was associated with Foxp $3^{\text {Low }}$ status $(P<0.001)$. No other significant associations between other features and TMIT classification were observed.

Next, we modified and adapted previously described molecular classification models for GC $[17,18]$ in our study population, according to the process described in Supplementary Figure 1. The GC cohort was classified into 5 molecular groups: $\mathrm{EBV}^{+}$(group 1), MSI-H (group 2), microsatellite stable (MSS)/MSI-low (MSI-L)/ EMT-like (group 3), MSS/MSI-L/p53-IHC (group 4), and MSS/MSI-L/p53-IHC ${ }^{-}$(group 5). Of the 392 patients, 25 were in group $1(6.4 \%)$, and 36 were group 2 (9.2\%); none 
Table 1: Clinicopathologic characteristics of study population

\begin{tabular}{|c|c|c|c|c|c|c|}
\hline & & Tumor microen & nent immune typ & & & \\
\hline & $\underset{\text { I }}{\text { PD-L1 }^{+} / \text {CD8 }^{\text {High }}}$ & $\begin{array}{c}\text { II } \\
\text { PD-L1 }^{-} / \mathrm{CD8}^{\mathrm{Low}}\end{array}$ & $\begin{array}{c}\text { III } \\
\text { PD-L1 }^{+} / \mathbf{C D 8}^{\text {Low }}\end{array}$ & $\begin{array}{c}\text { IV } \\
\text { PD-L1 }^{-} / \text {CD8 }^{\text {High }}\end{array}$ & Total & $P$ \\
\hline Age & $60(31-82)$ & $57(30-87)$ & $68(43-77)$ & $59(20-85)$ & $59(20-87)$ & 0.159 \\
\hline Sex & & & & & & 0.021 \\
\hline $\begin{array}{l}\text { Male } \\
\text { Female }\end{array}$ & $\begin{array}{l}70(27.7 \%) \\
19(13.7 \%)\end{array}$ & $\begin{array}{l}51(20.2 \%) \\
38(27.3 \%)\end{array}$ & $\begin{array}{l}9(3.6 \%) \\
0(0.0 \%)\end{array}$ & $\begin{array}{r}123(48.6 \%) \\
82(59.0 \%)\end{array}$ & $\begin{array}{l}253(64.5 \%) \\
139(35.5 \%)\end{array}$ & \\
\hline Lauren classifcation & & & & & & 0.765 \\
\hline $\begin{array}{l}\text { Intestinal } \\
\text { Diffuse } \\
\text { Mixed } \\
\text { Indeterminate }\end{array}$ & $\begin{array}{r}37(25.3 \%) \\
38(17.8 \%) \\
13(43.3 \%) \\
1(50.0 \%)\end{array}$ & $\begin{array}{r}29(19.9 \%) \\
58(27.1 \%) \\
2(6.7 \%) \\
0(0.0 \%)\end{array}$ & $\begin{array}{r}7(4.8 \%) \\
1(0.5 \%) \\
0(0.0 \%) \\
1(50.0 \%)\end{array}$ & $\begin{array}{r}73(50.0 \%) \\
117(54.7 \%) \\
15(50.0 \%) \\
0(0.0 \%)\end{array}$ & $\begin{array}{r}146(37.2 \%) \\
214(54.6 \%) \\
30(7.7 \%) \\
2(0.5 \%)\end{array}$ & \\
\hline Lymphatic invasion & & & & & & 0.698 \\
\hline $\begin{array}{l}\text { Absent } \\
\text { Present }\end{array}$ & $\begin{array}{l}23(19.7 \%) \\
66(24.0 \%)\end{array}$ & $\begin{array}{l}31(26.5 \%) \\
58(21.1 \%)\end{array}$ & $\begin{array}{l}0(0.0 \%) \\
9(3.3 \%)\end{array}$ & $\begin{array}{l}142(53.8 \%) \\
174(51.6 \%)\end{array}$ & $\begin{array}{l}117(29.8 \%) \\
275(70.2 \%)\end{array}$ & \\
\hline Vascular invasion & & & & & & 0.855 \\
\hline $\begin{array}{l}\text { Absent } \\
\text { Present }\end{array}$ & $\begin{array}{l}77(23.5 \%) \\
12(18.5 \%)\end{array}$ & $\begin{array}{l}70(21.4 \%) \\
19(29.2 \%)\end{array}$ & $\begin{array}{l}6(1.8 \%) \\
3(4.6 \%)\end{array}$ & $\begin{array}{r}174(53.2 \%) \\
31(47.7 \%)\end{array}$ & $\begin{array}{r}327(83.4 \%) \\
65(16.6 \%)\end{array}$ & \\
\hline Perineural invasion & & & & & & 0.266 \\
\hline $\begin{array}{l}\text { Absent } \\
\text { Present }\end{array}$ & $\begin{array}{l}40(30.5 \%) \\
49(18.8 \%)\end{array}$ & $\begin{array}{l}21(16.0 \%) \\
68(26.1 \%)\end{array}$ & $\begin{array}{l}3(2.3 \%) \\
6(2.3 \%)\end{array}$ & $\begin{array}{r}67(51.1 \%) \\
138(52.9 \%)\end{array}$ & $\begin{array}{l}131(33.4 \%) \\
261(66.6 \%)\end{array}$ & \\
\hline pT stage & & & & & & 0.004 \\
\hline $\begin{array}{l}\text { pT1 } \\
\text { pT2 } \\
\text { pT3 } \\
\text { pT4 }\end{array}$ & $\begin{array}{r}1(3.6 \%) \\
22(28.9 \%) \\
47(26.7 \%) \\
19(17.0 \%)\end{array}$ & $\begin{array}{r}3(10.7 \%) \\
7(9.2 \%) \\
39(22.2 \%) \\
40(35.7 \%)\end{array}$ & $\begin{array}{l}1(3.6 \%) \\
1(1.3 \%) \\
3(1.7 \%) \\
4(3.6 \%)\end{array}$ & $\begin{array}{l}23(82.1 \%) \\
46(60.5 \%) \\
87(49.4 \%) \\
49(43.8 \%)\end{array}$ & $\begin{array}{r}28(7.1 \%) \\
76(19.4 \%) \\
176(44.9 \%) \\
112(28.6 \%)\end{array}$ & \\
\hline $\begin{array}{c}\mathrm{pN} \text { stage } \\
\mathrm{pN} 0 \\
\mathrm{pN} 1 \\
\mathrm{pN} 2 \\
\mathrm{pN} 3\end{array}$ & $\begin{array}{l}10(21.3 \%) \\
47(29.4 \%) \\
14(13.1 \%) \\
18(23.1 \%)\end{array}$ & $\begin{array}{l}11(23.4 \%) \\
26(16.3 \%) \\
28(26.2 \%) \\
24(30.8 \%)\end{array}$ & $\begin{array}{l}1(2.1 \%) \\
4(2.5 \%) \\
2(1.9 \%) \\
2(2.6 \%)\end{array}$ & $\begin{array}{l}25(53.2 \%) \\
83(51.9 \%) \\
63(58.9 \%) \\
34(43.6 \%)\end{array}$ & $\begin{array}{r}47(12.0 \%) \\
160(40.8 \%) \\
107(27.3 \%) \\
78(19.9 \%)\end{array}$ & 0.839 \\
\hline $\begin{array}{l}\text { TNM stage } \\
\text { II } \\
\text { III }\end{array}$ & $\begin{array}{l}51(24.3 \%) \\
38(20.9 \%)\end{array}$ & $\begin{array}{l}33(15.7 \%) \\
56(30.8 \%)\end{array}$ & $\begin{array}{l}4(1.9 \%) \\
5(2.7 \%)\end{array}$ & $\begin{array}{r}122(58.1 \%) \\
83(45.6 \%)\end{array}$ & $\begin{array}{l}210(53.6 \%) \\
182(46.4 \%)\end{array}$ & 0.110 \\
\hline $\begin{array}{l}\text { Chemotherapy regimen } \\
\text { FP only } \\
\text { FP + cisplatin }\end{array}$ & $\begin{array}{r}80(23.9 \%) \\
9(16.1 \%)\end{array}$ & $\begin{array}{l}64(19.1 \%) \\
25(44.6 \%)\end{array}$ & $\begin{array}{l}9(2.7 \%) \\
0(0.0 \%)\end{array}$ & $\begin{array}{r}182(54.3 \%) \\
22(39.3 \%)\end{array}$ & $\begin{array}{r}335(85.7 \%) \\
56(14.3 \%)\end{array}$ & 0.177 \\
\hline Foxp3 IHC & & & & & & $<0.001$ \\
\hline $\begin{array}{l}\text { High } \\
\text { Low }\end{array}$ & $\begin{array}{l}79(88.8 \%) \\
10(11.2 \%)\end{array}$ & $\begin{array}{l}11(12.4 \%) \\
78(87.6 \%)\end{array}$ & $\begin{array}{l}5(55.6 \%) \\
4(44.4 \%)\end{array}$ & $\begin{array}{l}101(49.3 \%) \\
104(50.7 \%)\end{array}$ & $\begin{array}{l}196(50.0 \%) \\
196(50.0 \%)\end{array}$ & \\
\hline E-cadherin IHC & & & & & & 0.131 \\
\hline $\begin{array}{l}\mathrm{N} / \mathrm{C} \\
\mathrm{M}\end{array}$ & $\begin{array}{r}6(6.7 \%) \\
83(93.3 \%)\end{array}$ & $\begin{array}{l}18(20.2 \%) \\
71(79.8 \%)\end{array}$ & $\begin{array}{r}0(0.0 \%) \\
9(100.0 \%)\end{array}$ & $\begin{array}{r}37(18.0 \%) \\
168(82.0 \%)\end{array}$ & $\begin{array}{r}61(15.6 \%) \\
331(84.4 \%)\end{array}$ & \\
\hline p53 IHC & & & & & & 0.076 \\
\hline $\begin{array}{l}\text { Negative } \\
\text { Positive }\end{array}$ & $\begin{array}{l}69(77.5 \%) \\
20(22.5 \%)\end{array}$ & $\begin{array}{l}68(76.4 \%) \\
21(23.6 \%)\end{array}$ & $\begin{array}{l}6(66.7 \%) \\
3(33.3 \%)\end{array}$ & $\begin{array}{r}141(68.8 \%) \\
64(31.2 \%)\end{array}$ & $\begin{array}{l}284(72.4 \%) \\
108(27.6 \%)\end{array}$ & \\
\hline Total & $89(22.7 \%)$ & $89(22.7 \%)$ & $9(2.3 \%)$ & $205(52.3 \%)$ & $392(100.0 \%)$ & \\
\hline
\end{tabular}

Abbreviations: FP, fluoropyrimidine; IHC, immunohistochemistry; N / C, altered expression (negative or cytoplasmic); M, membranous staining; P, $p$-value. 
of the $\mathrm{EBV}^{+} \mathrm{GCs}$ showed an MSI-H phenotype, and vice versa. The number of patients in groups 3, 4, and 5 were $105(26.8 \%), 73(18.6 \%)$, and $153(39.0 \%)$, respectively.

\section{Survival analysis}

Kaplan-Meier survival analyses were performed, and the results showed that patients in the $\mathrm{CD} 8^{\text {High }}$ group had significantly better overall survival (OS) than the CD $8^{\text {Low }}$ group $(P<0.001$; Figure $2 \mathrm{~A})$, and that Foxp $3^{\text {High }}$ was associated with better $\mathrm{OS}(P=0.008$; Figure $2 \mathrm{~B})$ in stage II and III GC patients with standard treatment. There was no significant survival difference between $\mathrm{EBV}^{+}$and $\mathrm{EBV}^{-} \mathrm{GCs}(P=0.486$; Figure $2 \mathrm{C})$. Analysis according to MSI status showed that MSI-L patients had worse OS when compared to MSI-H and MSS patients, with borderline statistical significance $(P=0.063$; Figure 2D). PD-L1 IHC positivity itself was not significantly associated with survival $(P=0.579$; Supplementary Figure 2A), and there were no OS differences according to E-cadherin and p53 $\mathrm{IHC}(P=0.838$ and 0.216 , respectively; Supplementary Figure $2 \mathrm{~B}$ and $2 \mathrm{C}$ ).

We also performed Kaplan-Meier survival analysis according to TMIT and molecular classification. Of the 4 TMITs, type IV (PD-L1 ${ }^{-} / \mathrm{CD} 8^{\text {High }}$ ) had the best OS, and type II (PD-L1 $\left.{ }^{-} / \mathrm{CD}^{\mathrm{Low}}\right)$ had the worst OS $(P<0.001$; Figure 2E). Interestingly, when TMITs I and IV (the $\mathrm{CD} 8^{\text {High }}$ groups) were compared, type IV (PD-L1 ${ }^{-} / \mathrm{CD} 8^{\text {High }}$ ) had better OS, with marginal statistical significance $(P=0.070)$. However, according to the molecular

Type I

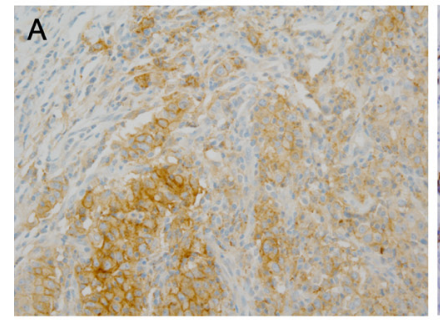

PD-L1 ${ }^{+}$

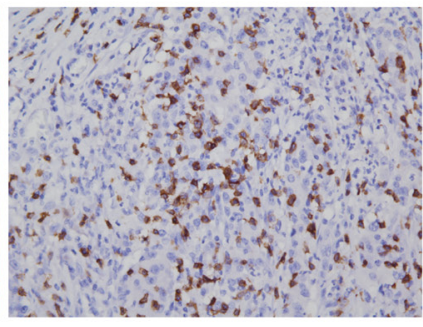

CD8 ${ }^{\text {High }}$
Type III

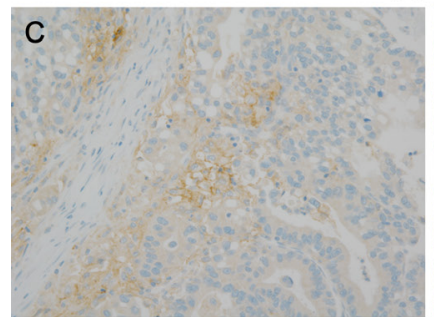

PD-L1+

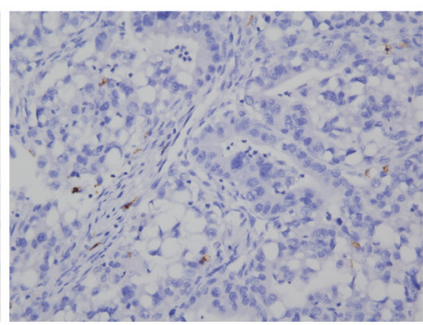

CD8 ${ }^{\text {Low }}$ classification, no significant survival differences were detected among the 5 groups $(P=0.791$; Figure $2 \mathrm{~F})$.

In addition, we performed survival analysis of disease free survival (DFS) (Supplementary Figure 3), which showed similar results when compared to the analysis of OS; high $\mathrm{CD}^{+}$, Foxp $^{+}$cells were associated with better DFS $(P<0.001$ and $P=0.021$, respectively), and TMIT IV showed the best DFS while TMIT II was associated with the worst DFS $(P<0.001)$.

Univariate analysis of OS by Cox proportional hazard model showed that age, vascular invasion, perineural invasion, chemotherapy regimen, TNM stage, $\mathrm{CD}^{+}$TILs, Foxp3 ${ }^{+}$TILs, and TMIT IV are the key clinicopathologic features that are significantly associated with OS (Table 2). By multivariate analysis, older age, the presence of vascular invasion, addition of cisplatin to FP-based chemotherapy, higher TNM stage, and CD8 ${ }^{\text {High }}$ status were significantly correlated with OS. Furthermore, when compared to the type I and II/III groups, TMIT IV was an independent prognostic factor for OS, with statistical significance (hazard ratios, 2.11 and 2.53; $95 \%$ confidence intervals, $1.03-4.33$ and $1.42-4.51$; and $P=0.042$ and 0.002 , respectively; Table 2, right column).

\section{Relationship between molecular classification and TMIT}

To determine the implications of the molecular classification from an immune microenvironment perspective, we compared TMIT and molecular

Type II

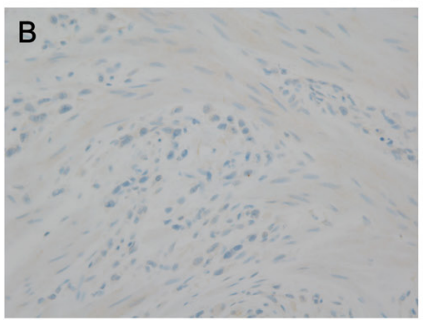

PD-L1-

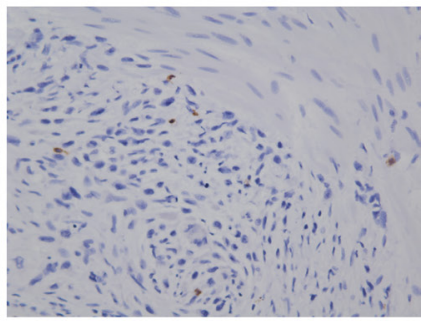

CD8 $8^{\text {Low }}$

Type IV

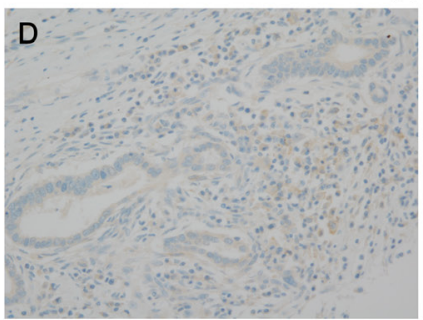

PD-L1-

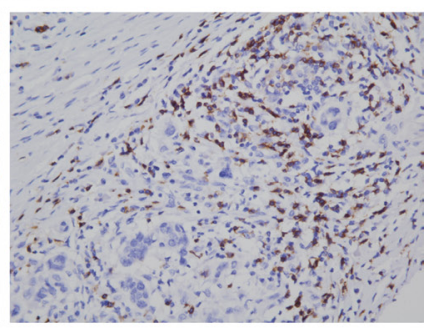

CD8 ${ }^{\mathrm{High}}$

Figure 1: Representative cases in each tumor microenvironment immune type (TMIT). The TMIT classification is as follows: (A) type I (PD-L1 $\left.{ }^{+} / \mathrm{CD} 8^{\text {High }}\right)$, (B) type II (PD-L1 $\left.{ }^{-} / \mathrm{CD} 8^{\text {Low }}\right),(\mathbf{C})$ type III (PD-L1 $\left.{ }^{+} / \mathrm{CD}^{\text {Low }}\right)$, and (D) type IV (PD-L1 $\left.{ }^{-} / \mathrm{CD} 8^{\text {High }}\right)$. PD$\mathrm{L1}^{+}$was defined as PD-L1 membrane staining in more than $5 \%$ of tumor cells (A, left; C, left), and CD8 ${ }^{\text {High }}$ was defined as a density of CD8 ${ }^{+}$ tumor infiltrating lymphocytes (TILs) exceeding the 25 th percentile (A, right; $\mathrm{D}$, right). 
classification. The relationship between the 2 classifications is shown in Table 3. Twenty-three of the $25(92 \%) \mathrm{EBV}^{+}$ GCs (group 1) were type I (PD-L1 $\left.{ }^{+} / \mathrm{CD}^{\mathrm{High}}\right)$; none of the $\mathrm{EBV}^{+} \mathrm{GCs}$ were CD8 ${ }^{\mathrm{Low}}$, and only $2(8.0 \%) \mathrm{EBV}^{+} \mathrm{GCs}$ were PD-L1 ${ }^{-}$. Similarly, MSI-H GCs (group 2) also had a distinct relationship with TMIT I; 26 of $36(72.3 \%)$ MSI-H cases were PD-L1 ${ }^{+}$, and 24 cases $(66.7 \%)$ were classified as TMIT I. Within group 3, only 4 of 105 (3.8\%) cases were TMIT I, and the proportion of TMIT II cases was relatively high $(35 / 105 ; 33.3 \%)$. In groups 4 and 5 , the proportion of each TMIT was similar to that from the whole study population.

\section{Validation using genomic data from TCGA and SMC cohort}

To validate the aforementioned association between TMIT I and $\mathrm{EBV}^{+}$or MSI-H GCs, we performed analysis of the genomic dataset from TCGA and SMC cohort. As shown in Figure $3 \mathrm{~A}$ and $3 \mathrm{~B}$, the majority of $\mathrm{EBV}^{+}$stomach adenocarcinomas in both datasets were classified as TMIT I (81.1\% in TCGA and $88.9 \%$ in SMC). Genomic analysis according to MSI status showed that, in accordance with the findings from our tissue samples, most of the MSI-H cases were TMIT I (70.5\% in TCGA and $76.5 \%$ in SMC), followed by type IV, II, and III (Figure 3C and 3D). In the MSS/MSI-L group, the proportions of each TMIT subtype in TCGA and SMC were similar to the proportions in our 392 patients.

Next, we assessed the expression of CDH1 in each TMIT to test for an association with molecular classification group 3, which shows EMT-like features. In TCGA dataset, TMIT IV showed the lowest $C D H 1$ expression, and only the difference between type IV and II showed statistical significance $(P=0.017$; Supplementary Figure 4A). In contrast, analysis of the SMC dataset showed that $C D H 1$ expression levels did not differ among the 4 TMITs. We also compared Foxp3 expression levels in TCGA dataset; type I showed significantly higher expression than the other types $(P<0.001$; Supplementary Figure 4B), and type IV showed the second highest expression. However, analysis of the SMC cohort did not show any differential Foxp3 expression among the 4 TMITs.

\section{DISCUSSION}

In this study, we classified a large cohort of stage II and III GC patients who were managed with standard treatment into one of four TMITs, using immunohistochemical assessment of PD-L1 expression and $\mathrm{CD}^{+}$TIL infiltration as the surrogate markers of the tumor microenvironment (TME). We found that TMIT I $\left(\mathrm{PD}-\mathrm{L1}^{+} / \mathrm{CD} 8^{\mathrm{High}}\right)$ is closely correlated with $\mathrm{EBV}$ infection
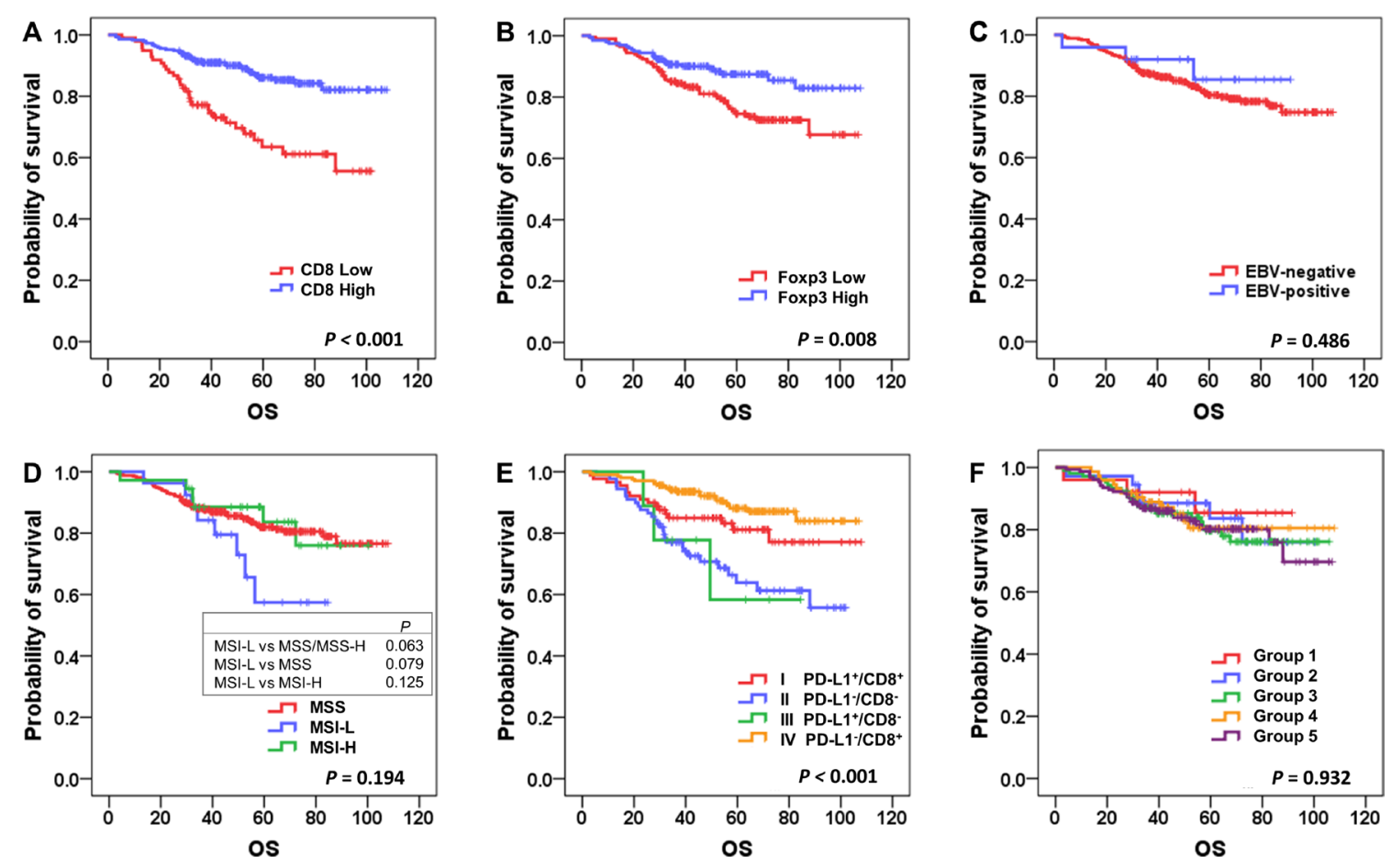

Figure 2: Kaplan-Meier survival analysis of overall survival according to major clinicopathologic features. Higher densities of CD8+ and Foxp3+ cells were associated with better overall survival (A and $\mathbf{B}$ ); $P<0.001$ and $P=0.008$, respectively), whereas Epstein-Barr virus (EBV) status was not a significant prognostic factor (C). Microsatellite instability-low (MSI-L) cases showed poor prognosis compared to others (D). There were significant survival differences among the 4 tumor microenvironment immune types (TMITs; E; $P<0.001)$, whereas there were no discernible differences according to molecular classification $(\mathbf{F})$. 
Table 2: Univariate and multivariate analysis of overall survival by Cox proportional hazards model

\begin{tabular}{|c|c|c|c|c|c|c|c|c|c|c|}
\hline \multirow{2}{*}{\multicolumn{2}{|c|}{ Variable }} & \multicolumn{3}{|c|}{ Univariate } & \multicolumn{3}{|c|}{ Multivariate (TMIT) } & \multicolumn{3}{|c|}{ Multivariate (CD8 ${ }^{+}$TILs) } \\
\hline & & \multirow{2}{*}{$\frac{\text { HR }}{1.03}$} & \multirow{2}{*}{$\frac{\mathbf{9 5 \%} \text { CI }}{1.01-1.05}$} & \multirow{2}{*}{$\frac{P}{0.002}$} & \multirow{2}{*}{$\frac{\text { HR }}{1.04}$} & \multirow{2}{*}{$\frac{\mathbf{9 5 \%} \text { CI }}{1.01-1.06}$} & \multirow{2}{*}{$\frac{P}{0.002}$} & \multirow{2}{*}{$\frac{\text { HR }}{1.04}$} & \multirow{2}{*}{$\frac{\mathbf{9 5 \%} \text { CI }}{1.01-1.06}$} & \multirow{2}{*}{$\frac{P}{0.002}$} \\
\hline Age & & & & & & & & & & \\
\hline Sex & $\begin{array}{l}\text { Female } \\
\text { vs male }\end{array}$ & 1.03 & $0.63-1.67$ & 0.920 & & & & & & \\
\hline $\begin{array}{l}\text { Lymphatic } \\
\text { invasion }\end{array}$ & $\begin{array}{l}\text { present } \\
\text { vs absent }\end{array}$ & 1.72 & $0.98-3.09$ & 0.070 & & & & & & \\
\hline $\begin{array}{l}\text { Vascular } \\
\text { invasion }\end{array}$ & $\begin{array}{l}\text { present } \\
\text { vs absent }\end{array}$ & 3.70 & $2.29-6.00$ & $<0.001$ & 1.99 & $1.19-3.32$ & 0.008 & 1.97 & $1.19-3.29$ & 0.009 \\
\hline $\begin{array}{l}\text { Perineural } \\
\text { invasion }\end{array}$ & $\begin{array}{l}\text { Present } \\
\text { vs absent }\end{array}$ & 3.08 & $1.58-6.01$ & 0.001 & 1.69 & $0.83-3.45$ & 0.149 & 1.63 & $0.80-3.31$ & 0.179 \\
\hline $\begin{array}{l}\text { Chemotherapy } \\
\text { regimen }\end{array}$ & $\begin{array}{l}\text { FP only } \\
\text { vs FP+C }\end{array}$ & 4.69 & $2.81-7.82$ & $<0.001$ & 3.55 & $2.01-6.26$ & $<0.001$ & 3.59 & $2.04-6.33$ & $<0.001$ \\
\hline TNM stage & III vs II & 6.12 & $3.34-11.20$ & $<0.001$ & 3.10 & $1.61-5.96$ & 0.001 & 3.15 & $1.64-6.08$ & 0.001 \\
\hline PD-L1 IHC & $\mathrm{P}$ vs $\mathrm{N}$ & 1.16 & $0.69-1.97$ & 0.579 & & & & & & \\
\hline $\mathrm{CD}^{+}$TILs & High vs Low & 0.34 & $0.21-0.55$ & $<0.001$ & & & & 0.46 & $0.27-0.78$ & 0.004 \\
\hline Foxp $3^{+}$TILs & High vs Low & 0.52 & $0.32-0.85$ & 0.009 & 0.87 & $0.45-1.66$ & 0.668 & 1.11 & $0.63-1.98$ & 0.717 \\
\hline EBV status & $\mathrm{P}$ vs $\mathrm{N}$ & 0.67 & $0.21-2.11$ & 0.489 & & & & & & \\
\hline \multirow[t]{2}{*}{ MSI status } & MSI-L vs MSS & 1.92 & $0.92-4.03$ & 0.085 & & & & & & \\
\hline & MSI-H vs MSS & 0.90 & $0.39-2.09$ & 0.808 & & & & & & \\
\hline E-cadherin IHC & $\mathrm{M}$ vs N/C & 1.07 & $0.56-2.04$ & 0.838 & & & & & & \\
\hline p53 IHC & P vs N & 1.37 & $0.83-2.26$ & 0.218 & & & & & & \\
\hline \multirow[t]{2}{*}{ TMIT } & I vs IV & 1.80 & $0.95-3.44$ & 0.073 & 2.11 & $1.03-4.33$ & 0.042 & & & \\
\hline & II/III vs IV & 3.62 & $2.10-6.24$ & $<0.001$ & 2.53 & $1.42-4.51$ & 0.002 & & & \\
\hline \multirow{4}{*}{$\begin{array}{l}\text { Molecular } \\
\text { classification }\end{array}$} & group 2 vs 1 & 1.27 & $0.32-5.07$ & 0.737 & & & & & & \\
\hline & group 3 vs 1 & 1.57 & $0.47-5.27$ & 0.464 & & & & & & \\
\hline & group 4 vs 1 & 1.39 & $0.39-4.91$ & 0.613 & & & & & & \\
\hline & group 5 vs 1 & 1.58 & $0.48-5.19$ & 0.454 & & & & & & \\
\hline
\end{tabular}

Abbreviations: HR, hazard ratio; CI, confidence interval; FP, fluoropyrimidine; C, cisplatin IHC, immunohistochemistry; , positive; N, negative; TIL, tumor infiltrating lymphocytes; MSI, microsatellite instability; MSI-L, MSI-low; MSI-H, MSIhigh; MSS, microsatellite stable; M, membranous statining; N/C, altered expression (negative or cytoplasmic); TMIT, tumor microenvironment immune types; $\mathrm{P}, p$-value.

and MSI-H phenotype than TMIT IV (PD-L1 ${ }^{-} / \mathrm{CD} 8^{\mathrm{High}}$ ). Additionally, to validate our results, we analysed datasets from TCGA [19] and the SMC cohort, the latter of which is a mostly Asian population [17]. The results also showed that the $\mathrm{EBV}^{+}$and MSI-H cases in the both datasets were likely to be type I ( $\left.P D-L 1^{\text {High }} / C D 8 A^{\text {High }}\right)$.

Numerous studies have shown that PD-L1 expression is increased in both $\mathrm{EBV}^{+}$and MSI-H GCs [20-22]. Likewise, it is well known that $\mathrm{EBV}^{+} \mathrm{GCs}$ and MSI-H GCs are associated with heavy lymphocytic infiltration [23, 24]. However, classification of the TME by co-assessment of PD-L1 and TILs had not yet been reported, and a study of a small Western population showed that $\mathrm{CD} 8^{+} \mathrm{T}$ cell-infiltrated GCs are associated with PD-L1 expression [25]. Here, we demonstrated, for the first time, the close association of TMIT I (PD-L1+/ $\mathrm{CD}^{\text {High }}$ ) with $\mathrm{EBV}^{+}$and MSI-H, compared to type IV (PD-L1 ${ }^{-} / \mathrm{CD}^{\mathrm{High}}$ ), using both tissue samples and genomic analysis. TMIT I status (PD-L1 ${ }^{+} / \mathrm{CD} 8^{\text {High }}$ ) implies the adaptive immune escape responses, and based on many previous studies, there is a good chance that GCs with this signature can be reversed by immune checkpoint blockade $[11,25]$. Therefore, we suggest that the type I (PD-L1 ${ }^{+} /$ CD8 ${ }^{\text {High }}$ ) TMIT could serve as a biomarker for a good response to immune checkpoint inhibitors, and that PD-L1 and CD8 TIL status should be evaluated in patients with $\mathrm{EBV}^{+}$or MSI-H GC.

In addition, we also found that the TMIT has prognostic value. TMIT II, which implies the immune ignorant state of tumor microenvironment, shows worse survival outcome compared to highly inflamed status (types I and IV), and this finding is consistent with previous studies from diverse tumor types including $\mathrm{GC}[21,23]$. Even more important finding from our survival analysis is that $\mathrm{OS}$ within the $\mathrm{CD} 8^{\text {High }}$ group differs according to the differential expression of PD-L1; type I (PD- $\mathrm{L}^{+} /$ 
Table 3: Comparison between molecular classification of gastric cancerand tumor microenvironment immune type

\begin{tabular}{|c|c|c|c|c|c|c|}
\hline \multicolumn{7}{|c|}{ Tumor microenvironment immune type } \\
\hline & $\begin{array}{c}\text { I } \\
\text { PD-L1 }^{+} / \mathbf{C D 8}^{\text {High }}\end{array}$ & $\begin{array}{c}\text { II } \\
\text { PD-L1 }^{-} / \text {CD8 }^{\text {Low }}\end{array}$ & $\begin{array}{c}\text { III } \\
\text { PD-L1 }^{+} / \mathbf{C D 8}^{\text {Low }}\end{array}$ & $\begin{array}{c}\text { IV } \\
\text { PD-L1 }^{-} / \text {CD8 }^{\text {High }}\end{array}$ & Total & $P$ \\
\hline Molecular classification & & & & & & $<0.001$ \\
\hline $\begin{array}{l}\text { Group } 1 \\
\mathrm{EBV}^{+}\end{array}$ & $\begin{array}{r}23 \\
(92.0 \%)\end{array}$ & $\begin{array}{r}0 \\
(0.0 \%)\end{array}$ & $\begin{array}{r}0 \\
(0.0 \%)\end{array}$ & $\begin{array}{r}2 \\
(8.0 \%)\end{array}$ & $\begin{array}{r}25 \\
(6.4 \%)\end{array}$ & \\
\hline $\begin{array}{l}\text { Group } 2 \\
\text { MSI-H }\end{array}$ & $\begin{array}{r}24 \\
(66.7 \%)\end{array}$ & $\begin{array}{r}5 \\
(13.9 \%)\end{array}$ & $\begin{array}{r}2 \\
(5.6 \%)\end{array}$ & $\begin{array}{r}5 \\
(13.9 \%)\end{array}$ & $\begin{array}{r}36 \\
(9.2 \%)\end{array}$ & \\
\hline $\begin{array}{l}\text { Group } 3 \\
\text { MSS/MSI-L/EMT-like }\end{array}$ & $\begin{array}{r}4 \\
(3.8 \%)\end{array}$ & $\begin{array}{r}35 \\
(33.3 \%)\end{array}$ & $\begin{array}{r}0 \\
(0.0 \%)\end{array}$ & $\begin{array}{r}66 \\
(62.9 \%)\end{array}$ & $\begin{array}{r}105 \\
(26.8 \%)\end{array}$ & \\
\hline $\begin{array}{l}\text { Group } 4 \\
\text { MSS/MSI-L/p53-IHC+ }\end{array}$ & $\begin{array}{r}13 \\
(17.8 \%)\end{array}$ & $\begin{array}{r}13 \\
(17.8 \%)\end{array}$ & $\begin{array}{r}3 \\
(4.1 \%)\end{array}$ & $\begin{array}{r}44 \\
(60.3 \%)\end{array}$ & $\begin{array}{r}73 \\
(18.6 \%)\end{array}$ & \\
\hline $\begin{array}{l}\text { Group } 5 \\
\text { MSS/MSI-L/p53-IHC- }\end{array}$ & $\begin{array}{r}25 \\
(16.3 \%)\end{array}$ & $\begin{array}{r}36 \\
(23.5 \%)\end{array}$ & $\begin{array}{r}4 \\
(2.6 \%)\end{array}$ & $\begin{array}{r}88 \\
(57.5 \%)\end{array}$ & $\begin{array}{r}153 \\
(39.0 \%)\end{array}$ & \\
\hline Total & $\begin{array}{r}89 \\
(22.7 \%)\end{array}$ & $\begin{array}{r}89 \\
(22.7 \%)\end{array}$ & $\begin{array}{r}9 \\
(2.3 \%)\end{array}$ & $\begin{array}{r}205 \\
(52.3 \%)\end{array}$ & $\begin{array}{r}392 \\
(100.0 \%)\end{array}$ & \\
\hline
\end{tabular}

Abbreviations: EBV, Ebstein-Barr virus; MSI-H, microsatellite instability high; MSI-L, microsatellite instability low; MSS, microsatellite stable; EMT, epithelial mesenchymal transition; IHC, immunohistochemistry; P, $p$-value .

$\mathrm{CD}^{\text {High }}$ ) showed significantly poorer OS than type IV (PD-L1 ${ }^{-} / \mathrm{CD}^{\mathrm{High}}$ ) by multivariate analysis. From this we could infer that although heavy immune cell infiltration might play the favorable anti-tumor effect in gastric cancer, effective immune evading occurs by expression of PD-L1, possibly resulting in decreased OS. Since PDL1 expression alone failed to discriminate survival in the total study population, the significant survival difference
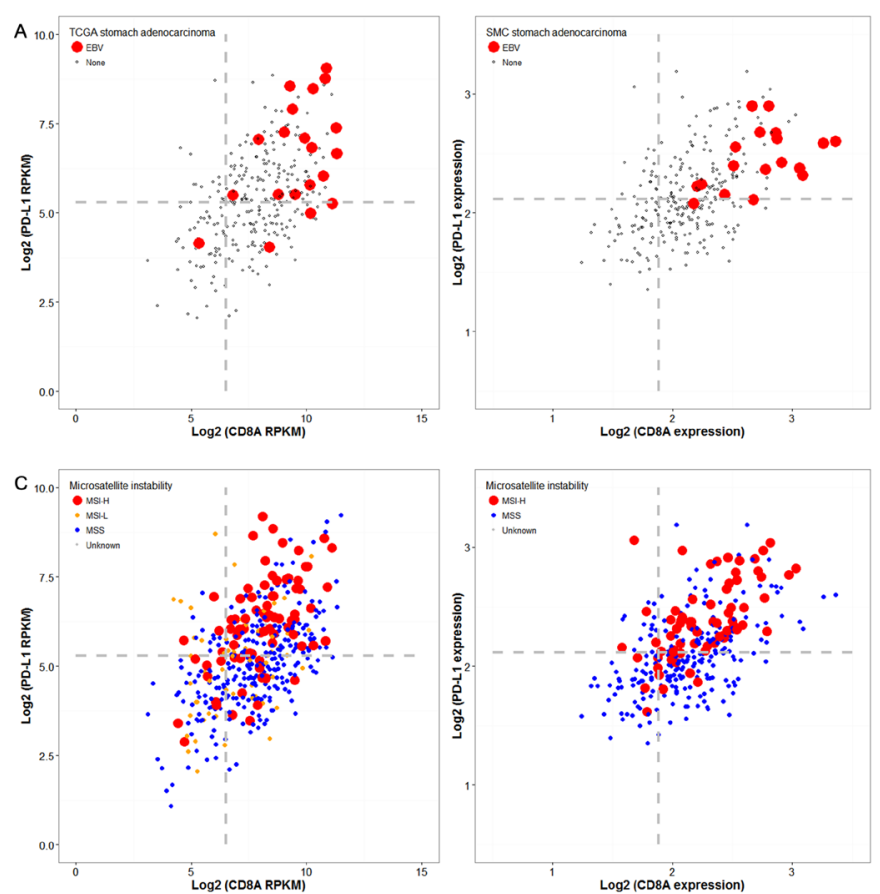
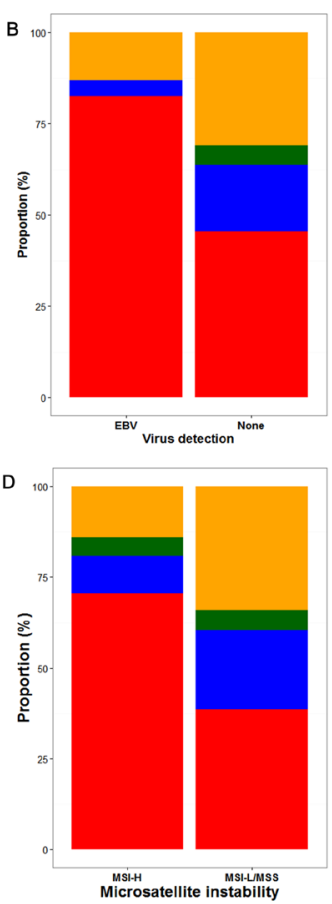
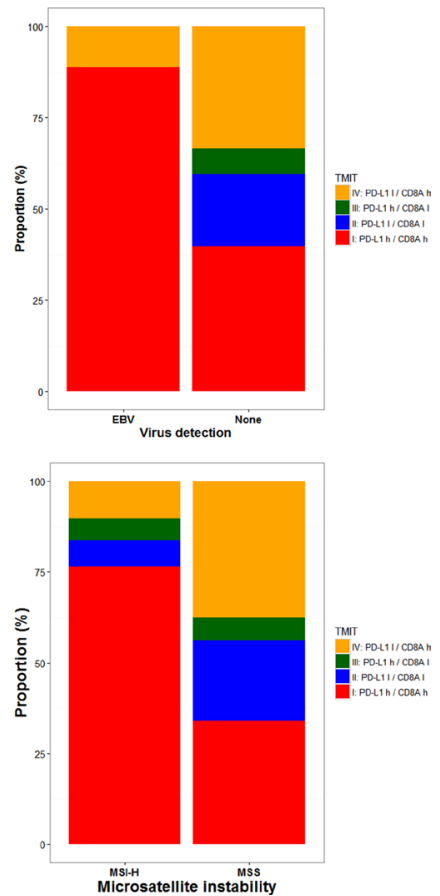

Figure 3: Genomic analysis of the cancer genome atlas (TCGA) and samsung medical center (SMC) cohort datasets according to Epstein-Barr virus (EBV) and microsatellite instability (MSI) status. The $P D-L 1 / C D 8 A$ expression patterns according to EBV status in TCGA (left) and SMC (right) datasets are shown (A), and EBV-positivity (red dots) was associated with higher expression of both PD-L1 and CD8A. Concordantly, more than $75 \%$ of the cases in both datasets were tumor microenvironment immune type (TMIT) I (red box) (B). Similarly, MSI-H cases (red dots) were associated with higher PD-L1/CD8A expression (C) TCGA (left) and SMC (right)), and were thus TMIT I (red box) (D). 
elucidated by differential PD-L1 expression in the CD8 $8^{\text {High }}$ group strongly suggests that the clinical implication of PD-L1 expression could become more meaningful when interpreted in combination with other components of the TME. Therefore, we suggest co-assessment of both PD-L1 and $\mathrm{CD}^{+}$TILs as a useful way of defining the TME, which also has a significant prognostic role in stage II and III GC.

Previous studies on the prognostic role of PD-L1 expression in GC showed conflicting results. For example, the most recent study of a large Caucasian cohort of GC showed that PD-L1 expression in tumor and stromal immune cells was associated with better tumor-specific and overall survival [26], while previous studies of an Asian population showed the poor prognostic role of PD-L1 expression [27, 28]. Some authors attributed these discrepant results to differences in the gene signatures between the Asian and Caucasian populations [26, 29]. Apart from ethnicity, we suggest other explanations for the conflicting results. Previous survival analyses of GC according to PD-L1 expression were not performed within the context of the immune microenvironment, as discussed earlier. Furthermore, most studies were performed on heterogeneous populations; that is, patients with cancers of various stages with different clinical settings and treatment strategies. In contrast, our study population was relatively homogenous. In Korea, the 5-year survival rate of the localized gastric cancer patients exceeds $92 \%$ [30], therefore, when performing prognostic analysis within the localized gastric cancer group, the chance that the survival outcome of this group may not be directly related to disease itself must be taken into account. In cases of metastatic gastric cancer, the therapeutic approach including chemotherapy regimen widely varies [31], and this heterogeneity may result in possible confounder of the survival analysis. For these reasons, we have restricted the study population into patients with stage II and III GC who were treated by curative surgical resection followed by FP-based adjuvant chemotherapy, with the expectation of causing less bias in the survival analysis. Therefore, we suggest that the prognostic difference found in the present study of stage II and III GCs is notable and very reliable.

Next, we assessed the characteristics that distinguished type IV (PD-L1 ${ }^{-} / \mathrm{CD} 8^{\text {High }}$ ) from type I $\left(\mathrm{PD}-\mathrm{L} 1^{+} / \mathrm{CD} 8^{\text {High }}\right)$ GCs. The characteristic immune microenvironment of type IV is activation of the immunesuppressing mechanism other than PD-L1. Therefore, we assessed the role of Tregs in type IV GCs by measuring Foxp3 expression by IHC. Contrary to our assumption, the proportions of Foxp $3^{\text {High }}$ and Foxp $3^{\text {Low }}$ within the type IV group were approximately equal, and analysis of TCGA and SMC datasets did not show discernible high expression of Foxp 3 in type IV, suggesting that the immune tolerance mechanism in type IV cannot be solely explained by Tregs. Further studies on the various components of the TME in the type IV group, such as tumor-associated macrophages or myeloid-derived suppressor cells should provide a deeper understanding of this topic.

Since the introduction of molecular subtypes of GC in TCGA study, $\mathrm{EBV}^{+}$GCs and MSI-H GCs have been consistently regarded as distinct subtypes [19]. Yet, debates regarding the proper classification of the remaining GCs continue, and little is known about these GCs from an immuno-oncologic perspective. Recently, Setia et al. suggested a practical molecular classification model mainly based on IHC analysis of E-cadherin and p53 [18], which we adapted in this study. Based on the previous findings for other types of solid tumors, group 3 (MSS/MSI-L/EMTlike) was expected to be positively associated with PD-L1 expression [32,33]. However, only $3.1 \%$ of group 3 cases $(4 / 105)$ were PD-L1 $1^{+}$. This may be due to differences in the biology of GC compared to that of the other cancers for which strong associations were observed. A more precise definition of 'EMT-like' is warranted to specify the immuno-oncologic characteristics of this category. When groups 4 (MSS/non-EMT-like/p53-IHC ${ }^{+}$) and 5 (MSS/ non-EMT-like/ p53-IHC ${ }^{-}$) were compared according to classification, the proportions of the 4 TMITs within these 2 groups were similar to the proportions in the total population; thus, no distinct immuno-oncologic features according to p53 overexpression were observed.

This study has the limitation of being a retrospective study at a single institution. However, compared to other studies, our study population is a large, relatively homogeneous cohort with restricted confounding factors. The cut-off value for PD-L1 ${ }^{+}$is still a matter of debate; applying different cut-off level for PD-L1 IHC results would inevitably result in different proportions among the TMIT subtypes. However, since there is no general consensus in this topic till nowadays, we have done thorough review of previous studies in pursuit of identifying an ideal cut-off criteria for PD-L1 IHC, and chose our criteria referenced from the most recent studies of GC $[20,25]$. In addition, this study was based on the immunostainings on TMA blocks, which enabled us to assess PD-L1 expression in a large cohort of 392 patients. Despite, it is reported that spatial heterogeneity of PD-L1 IHC exists in various types of tumor including non-small cell lung cancer and malignant melanoma [34]. Therefore, even though we have applied 5\% positivity as the cutoff for PD-L1 IHC, the possibility of false-negativity should be considered. We have found that to date, there is no consensus on the assessment methods for TILs and their cut-offs. Here, we adapted previously described image-analyzer method [35] to ensure objectivity. For the molecular classification, we could not clearly define the distinct immunologic characteristics of GCs other than $\mathrm{EBV}^{+} \mathrm{GC}$ and MSI-H GC. This can be attributable to the limitation of IHC itself; we have interpreted p53 IHC into 
either positive or negative, however, this may not reflect the actual TP53 gene mutation status accurately. Thus, more precise techniques for assessing genetic mutation and gene expression levels should be warranted in future studies.

In summary, this is the first study to classify a large homogeneous cohort of stage II and III GCs into 4 immune types by co-assessment of 2 key components of TME, PD-L1 expression and $\mathrm{CD}^{+} \mathrm{T}$ cell infiltration. We found that $\mathrm{EBV}^{+}$and MSI-H GCs are distinct subtypes that are tightly associated with TMIT I (PD-L1 ${ }^{+} / \mathrm{CD}^{\text {High }}$ ), and OS within the $\mathrm{CD} 8^{\text {High }}$ group differs according to PD-L1 expression. Therefore, we conclude that co-assessment of PD-L1 and CD8 ${ }^{+}$TILs is clinically relevant, has a possible prognostic role, and warrants further investigation as a predictive marker for immune checkpoint blockade.

\section{MATERIALS AND METHODS}

\section{Patients and samples}

A total of consecutive 406 patients with stage II or III GC who were treated in Seoul National University Bundang Hospital (Seongnam-si, Republic of Korea) from 2006 to 2013 were screened for inclusion. Among them, the tumor tissue samples of 14 patients were found inadequate for immunohistochemistry, thus excluded (Supplementary Figure 5). All 392 patients who were included in final analysis underwent curative surgical resection (R0 resection) with $\mathrm{D} 2$ lymph node dissection followed by fluoropyrimidine (FP)-based adjuvant chemotherapy (5-fluorouracil (5-FU), capecitabine, or S-1 with cisplatin, if clinically indicated). Clinicopathologic characteristics, including overall survival (OS) and disease free survival (DFS) were obtained retrospectively from medical records and pathology reports. OS was defined as the time from surgery to the date of death by any cause or censoring, and DFS was defined as the time from surgery to the date of recurrence of disease.

Surgically resected GC specimens from patients were formalin-fixed and paraffin-embedded (FFPE). In all cases, one representative $2-\mathrm{mm}$ core was selected from the invasive margin of the tumor by 2 experienced gastrointestinal pathologists (S.Y. and H.S.L.), and tissue microarrays (TMA) were constructed as described previously (Superbiochips Laboratories, Seoul, Republic of Korea) [36].

All human FFPE tissue samples were obtained from the archive of the Department of Pathology, Seoul National University Bundang Hospital. This study was approved by the institutional review board (IRB) of Seoul National University Bundang Hospital (IRB number: B-1606/349-308). Written patient consent and the consent process were waived by the IRB.

\section{IHC and EBV in situ hybridization (ISH)}

IHC for CD8, Foxp3, E-cadherin, p53, and PDL1 were performed with an automatic immunostainer (BenchMark XT; Ventana Medical Systems, Tucson, AZ, USA), according to the manufacturer's instructions. The IHC antibodies used in this study were as follows: CD8 (C8/114B, mouse monoclonal; Dako, Carpinteria, CA, USA); Foxp3 (236A/E7, mouse monoclonal; Abcam, Cambridge, UK); E-cadherin (clone 36, mouse monoclonal; BD Biosciences, Franklin Lakes, NJ, USA); p53 (DO7, mouse monoclonal; Dako); and PD-L1 (E1L3N, rabbit monoclonal; Cell Signaling Technology, Danvers, MA, USA). EBV ISH was performed with the INFORM EBV-encoded RNA (EBER) probe (Ventana Medical Systems).

To interpret the CD8 and Foxp3 staining, immunostained TMA slides were scanned, and the $\mathrm{CD}^{+}$ and Foxp $3^{+}$cell densities (positive cell counts per $\mathrm{mm}^{2}$ ) in each core of TMA were counted by an Aperio image analysis system (Leica Biosystems, New Castle, UK). The $\mathrm{CD} 8^{\text {High }}$ and $\mathrm{CD} 8^{\text {Low }}$ groups were defined using the 25 th percentile as the cut-off value, and median value was used as the cut-off for Foxp3.

All other immunostaining was interpreted by 2 pathologists (J.K. and H.S.L.) who were blinded to patient characteristics at the time of interpretation. Membrane staining of PD-L1 on more than $5 \%$ of tumor cells was interpreted as positive $[20,25]$. For E-cadherin, complete loss of membrane staining or aberrant cytoplasmic staining was regarded as altered expression, while complete membrane staining as strong as that in the non-neoplastic epithelium was considered normal expression [37]. For p53, strong nuclear staining in more than $10 \%$ of tumor cells was interpreted as p53 overexpression/positive, and cases with less than $10 \%$ positive cells including those showing scattered positive or patchy positive cells were considered negative. [38].

\section{PD-L1 mRNA ISH}

To detect $P D-L 1$ mRNA on the tissue microarray, the $P D$-L1 RNAscope 2-plex detection kit (Advanced Cell Diagnostics, Hayward, CA, USA) was used according to the manufacturer's guidelines. The results were interpreted by 2 pathologists (J.K. and H.S.L.) according to the instructions in the RNAscope FFPE Assay Kit and were scored as described previously [39]: 0, no staining; 1 , staining in $<10 \%$ of tumor cells, difficult to identify at $40 \times ; 2$, staining in $\geq 10 \%$ of tumor cells, difficult to identify at $20 \times$ but easy at $40 \times$; 3 , staining in $\geq 10 \%$ of tumor cells, difficult to identify at $10 \times$ but easy at $20 \times ; 4$, staining in $\geq 10 \%$ of tumor cells, easy to identify at $10 \times$. A score of 4 was considered $P D-L 1$ overtranscription. 


\section{Microsatellite instability (MSI)}

MSI status was assessed by comparing the allele profiles of 5 markers (BAT-26, BAT-25, D5S346, D17S250, and S2S123) in tumor cells to those in matched normal samples. The polymerase chain reaction (PCR) products from the FFPE samples were analysed with a DNA autosequencer (ABI 3731 Genetic Analyzer; Applied Biosystems, Foster City, CA, USA) according to a previously described protocol [40].

\section{Processing and analysis of genomic data}

We used the publicly available level 3 data from TCGA downloaded from the UCSC Cancer Browser (http://genome-cancer.ucsc.edu) on June 3, 2015, which included clinical information and mRNA expression data obtained by RNAseq (Illumina HiSeq V2 platform) of TCGA samples. The mRNA expression data were presented as reads per kilobase per million (RPKM) and were transformed into $\log 2$ values for the analysis. MSI status was available for 414 stomach adenocarcinoma (STAD) samples, and EBV status was referenced from TCGA clinical data.

In addition, we obtained clinical and mRNA expression data from a SMC cohort (Samsung Medical Center, Seoul, Republic of Korea) shared by Cristescu and colleagues [17] (Gene Expression Omnibus, GSE62254) on April 17, 2015. The mRNA expression data were processed by the Affymetrix Human Genome U133plus 2.0 Array (Santa Clara, CA, USA).

For application of the TMIT classification to the genomic data, after merging the log 2-transformed RPKM values of $P D-L 1$ and $C D 8 A$, we divided TCGA and SMC cohort samples into 4 groups using the aforementioned cut-off values (the median for $P D-L 1$ and lower 25th percentile for $C D 8 A$ ).

\section{Statistical analysis}

The associations between clinicopathological characteristics and TMITs were analysed by Chi-square, linear-by-linear, Kruskal-Wallis, and Wilcoxson/MannWhitney tests, if appropriate. Spearman rank correlation was used for the correlation analysis between PD-L1 IHC and $P D-L 1$ mRNA ISH. Kaplan-Meier analysis of OS and DFS according to TMIT and molecular classification was performed, and the significance of survival differences was assessed by the log-rank test. A $P$-value less than 0.05 was considered statistically significant. All statistical analyses were performed using SPSS statistics 22.0 (IBM, Armonk, NY, USA), with the exception of the genomic analysis and data presentation which were performed using the $\mathrm{R}$ statistical package 3.1.3 (http://www.r-project.org).

\section{CONFLICTS OF INTEREST}

The authors have declared no conflicts of interest.

\section{FUNDING}

This research was supported by Basic Science Research Program through the National Research Foundation of Korea (NRF) funded by the Ministry of Education (NRF-2016R1D1A1B03931744). The funder had no role in study design, data collection and analysis, decision to publish, or preparation of the manuscript.

\section{REFERENCES}

1. Jemal A, Bray F, Center MM, Ferlay J, Ward E, Forman D. Global cancer statistics. CA Cancer J Clin. 2011; 61:69-90.

2. Jung KW, Won YJ, Oh CM, Kong HJ, Cho H, Lee JK, Lee DH, Lee KH. Prediction of Cancer Incidence and Mortality in Korea, 2016. Cancer Res Treat. 2016; 48:451-457.

3. Ferlay J, Soerjomataram I, Dikshit R, Eser S, Mathers C, Rebelo M, Parkin DM, Forman D, Bray F. Cancer incidence and mortality worldwide: sources, methods and major patterns in GLOBOCAN 2012. Int J Cancer. 2015; 136:E359-386.

4. Suzuki H, Iwasaki E, Hibi T. Helicobacter pylori and gastric cancer. Gastric Cancer. 2009; 12:79-87.

5. van Beek J, zur Hausen A, Klein Kranenbarg E, van de Velde CJ, Middeldorp JM, van den Brule AJ, Meijer CJ, Bloemena E. EBV-positive gastric adenocarcinomas: a distinct clinicopathologic entity with a low frequency of lymph node involvement. J Clin Oncol. 2004; 22:664-670.

6. Das S, Suarez G, Beswick EJ, Sierra JC, Graham DY, Reyes VE. Expression of B7-H1 on Gastric Epithelial Cells: Its Potential Role in Regulating $\mathrm{T}$ Cells during Helicobacter pylori Infection. The Journal of Immunology. 2006; 176:3000-3009.

7. Ansell SM, Lesokhin AM, Borrello I, Halwani A, Scott EC, Gutierrez M, Schuster SJ, Millenson MM, Cattry D, Freeman GJ, Rodig SJ, Chapuy B, Ligon AH, et al. PD-1 blockade with nivolumab in relapsed or refractory Hodgkin's lymphoma. N Engl J Med. 2015; 372:311-319.

8. Herbst RS, Soria JC, Kowanetz M, Fine GD, Hamid O, Gordon MS, Sosman JA, McDermott DF, Powderly JD, Gettinger SN, Kohrt HE, Horn L, Lawrence DP, et al. Predictive correlates of response to the anti-PD-L1 antibody MPDL3280A in cancer patients. Nature. 2014; 515:563-567.

9. Hodi FS, O’Day SJ, McDermott DF, Weber RW, Sosman JA, Haanen JB, Gonzalez R, Robert C, Schadendorf D, Hassel JC, Akerley W, van den Eertwegh AJ, Lutzky J, et al. Improved survival with ipilimumab in patients with metastatic melanoma. N Engl J Med. 2010; 363:711-723. 
10. Muro K, Chung HC, Shankaran V, Geva R, Catenacci D, Gupta S, Eder JP, Golan T, Le DT, Burtness B, McRee AJ, Lin CC, Pathiraja K, et al. Pembrolizumab for patients with PD-L1-positive advanced gastric cancer (KEYNOTE-012): a multicentre, open-label, phase $1 \mathrm{~b}$ trial. The Lancet Oncology. 2016; 17:717-726.

11. Taube JM, Anders RA, Young GD, Xu H, Sharma R, McMiller TL, Chen S, Klein AP, Pardoll DM, Topalian SL, Chen L. Colocalization of inflammatory response with B7-h1 expression in human melanocytic lesions supports an adaptive resistance mechanism of immune escape. Sci Transl Med. 2012; 4:127ra137.

12. Teng MW, Ngiow SF, Ribas A, Smyth MJ. Classifying Cancers Based on T-cell Infiltration and PD-L1. Cancer Res. 2015; 75:2139-2145.

13. Ock CY, Keam B, Kim S, Lee JS, Kim M, Kim TM, Jeon YK, Kim DW, Chung DH, Heo DS. PanCancer Immunogenomic Perspective on the Tumor Microenvironment Based on PD-L1 and CD8 T-Cell Infiltration. Clin Cancer Res. 2016; 22:2261-2270.

14. Tumeh PC, Harview CL, Yearley JH, Shintaku IP, Taylor EJ, Robert L, Chmielowski B, Spasic M, Henry G, Ciobanu V, West AN, Carmona M, Kivork C, et al. PD-1 blockade induces responses by inhibiting adaptive immune resistance. Nature. 2014; 515:568-571.

15. Choi YY, Noh SH, Cheong JH. Molecular Dimensions of Gastric Cancer: Translational and Clinical Perspectives. J Pathol Transl Med. 2016; 50:1-9.

16. Rooney MS, Shukla SA, Wu CJ, Getz G, Hacohen N. Molecular and genetic properties of tumors associated with local immune cytolytic activity. Cell. 2015; 160:48-61.

17. Cristescu R, Lee J, Nebozhyn M, Kim KM, Ting JC, Wong SS, Liu J, Yue YG, Wang J, Yu K, Ye XS, Do IG, Liu S, et al. Molecular analysis of gastric cancer identifies subtypes associated with distinct clinical outcomes. Nat Med. 2015; 21:449-456.

18. Setia N, Agoston AT, Han HS, Mullen JT, Duda DG, Clark JW, Deshpande V, Mino-Kenudson M, Srivastava A, Lennerz JK, Hong TS, Kwak EL, Lauwers GY. A protein and mRNA expression-based classification of gastric cancer. Mod Pathol. 2016; 29:772-784.

19. Cancer Genome Atlas Research N. Comprehensive molecular characterization of gastric adenocarcinoma. Nature. 2014; 513:202-209.

20. Derks S, Liao X, Chiaravalli AM, Xu X, Camargo MC, Solcia E, Sessa F, Fleitas T, Freeman GJ, Rodig SJ, Rabkin CS, Bass AJ. Abundant PD-L1 expression in Epstein-Barr Virus-infected gastric cancers. Oncotarget. 2016; 7:32925-32. doi: 10.18632/oncotarget.9076.

21. Kim JH, Park HE, Cho NY, Lee HS, Kang GH. Characterisation of PD-L1-positive subsets of microsatelliteunstable colorectal cancers. Br J Cancer. 2016; 115:490-496.

22. Kim SY, Park C, Kim HJ, Park J, Hwang J, Kim JI, Choi MG, Kim S, Kim KM, Kang MS. Deregulation of immune response genes in patients with Epstein-Barr virusassociated gastric cancer and outcomes. Gastroenterology. 2015; 148:137-147 e139.

23. Kim KJ, Lee KS, Cho HJ, Kim YH, Yang HK, Kim WH, Kang GH. Prognostic implications of tumor-infiltrating FoxP3+ regulatory $\mathrm{T}$ cells and $\mathrm{CD} 8+$ cytotoxic $\mathrm{T}$ cells in microsatellite-unstable gastric cancers. Hum Pathol. 2014; 45:285-293.

24. Li Z, Lai Y, Sun L, Zhang X, Liu R, Feng G, Zhou L, Jia L, Huang X, Kang Q, Lin D, Gao J, Shen L. PD-L1 expression is associated with massive lymphocyte infiltration and histology in gastric cancer. Hum Pathol. 2016; 55:182-189.

25. Thompson ED, Zahurak M, Murphy A, Cornish T, Cuka N, Abdelfatah E, Yang S, Duncan M, Ahuja N, Taube JM, Anders RA, Kelly RJ. Patterns of PD-L1 expression and CD8 $\mathrm{T}$ cell infiltration in gastric adenocarcinomas and associated immune stroma. Gut. 2016; 66:794-801.

26. Boger C, Behrens HM, Mathiak M, Kruger S, Kalthoff H, Rocken C. PD-L1 is an independent prognostic predictor in gastric cancer of Western patients. Oncotarget. 2016; 7:24269-83. doi: 10.18632/oncotarget.8169.

27. Eto S, Yoshikawa K, Nishi M, Higashijima J, Tokunaga T, Nakao T, Kashihara H, Takasu C, Iwata T, Shimada M. Programmed cell death protein 1 expression is an independent prognostic factor in gastric cancer after curative resection. Gastric Cancer. 2016; 19:466-471.

28. Zhang L, Qiu M, Jin Y, Ji J, Li B, Wang X, Yan S, $\mathrm{Xu}$ R, Yang D. Programmed cell death ligand 1 (PD-L1) expression on gastric cancer and its relationship with clinicopathologic factors. International journal of clinical and experimental pathology. 2015; 8:11084-11091.

29. Shen L, Shan YS, Hu HM, Price TJ, Sirohi B, Yeh KH, Yang YH, Sano T, Yang HK, Zhang X, Park SR, Fujii M, Kang YK, et al. Management of gastric cancer in Asia: resource-stratified guidelines. The Lancet Oncology. 2013; 14:e535-547.

30. Jung KW, Won YJ, Kong HJ, Oh CM, Shin A, Lee JS. Survival of korean adult cancer patients by stage at diagnosis, 2006-2010: national cancer registry study. Cancer Res Treat. 2013; 45:162-171.

31. Lee JH, Kim JG, Jung HK, Kim JH, Jeong WK, Jeon TJ, Kim JM, Kim YI, Ryu KW, Kong SH, Kim HI, Jung HY, Kim YS, et al. Clinical practice guidelines for gastric cancer in Korea: an evidence-based approach. J Gastric Cancer. 2014; 14:87-104.

32. Kim S, Koh J, Kim MY, Kwon D, Go H, Kim YA, Jeon YK, Chung DH. PD-L1 expression is associated with epithelialto-mesenchymal transition in adenocarcinoma of the lung. Hum Pathol. 2016; 58:7-14. doi: 10.18632/oncotarget.7431.

33. Ock CY, Kim S, Keam B, Kim M, Kim TM, Kim JH, Jeon YK, Lee JS, Kwon SK, Hah JH, Kwon TK, Kim DW, $\mathrm{Wu} \mathrm{HG}$, et al. PD-L1 expression is associated with epithelialmesenchymal transition in head and neck squamous cell carcinoma. Oncotarget. 2016; 7:15901-15914. 
34. Rehman JA, Han G, Carvajal-Hausdorf DE, Wasserman BE, Pelekanou V, Mani NL, McLaughlin J, Schalper KA, Rimm DL. Quantitative and pathologist-read comparison of the heterogeneity of programmed death-ligand 1 (PD-L1) expression in non-small cell lung cancer. Mod Pathol. 2016; 30:340-349.

35. Kim Y, Bae JM, Li G, Cho NY, Kang GH. Image analyzerbased assessment of tumor-infiltrating $\mathrm{T}$ cell subsets and their prognostic values in colorectal carcinomas. PLoS One. 2015; 10:e0122183.

36. Lee KS, Nam SK, Koh J, Kim DW, Kang SB, Choe G, Kim WH, Lee HS. Stromal Expression of MicroRNA-21 in Advanced Colorectal Cancer Patients with Distant Metastases. J Pathol Transl Med. 2016; 50:270-277.

37. Yi Kim D, Kyoon Joo J, Kyu Park Y, Yeob Ryu S, Soo Kim H, Kyun Noh B, Hwa Lee K, Hyuk Lee J. E-cadherin expression in early gastric carcinoma and correlation with lymph node metastasis. J Surg Oncol. 2007; 96:429-435.

38. Chang MS, Lee JH, Kim JP, Kim HS, Lee HS, Kim CW, Kim YI, Kim WH. Microsatellite instability and EpsteinBarr virus infection in gastric remnant cancers. Pathology international. 2000; 50:486-492.

39. Kim MA, Jung JE, Lee HE, Yang HK, Kim WH. In situ analysis of HER2 mRNA in gastric carcinoma: comparison with fluorescence in situ hybridization, dual-color silver in situ hybridization, and immunohistochemistry. Hum Pathol. 2013; 44:487-494.

40. Oh JR, Kim DW, Lee HS, Lee HE, Lee SM, Jang JH, Kang SB, Ku JL, Jeong SY, Park JG. Microsatellite instability testing in Korean patients with colorectal cancer. Fam Cancer. 2012; 11:459-466. 